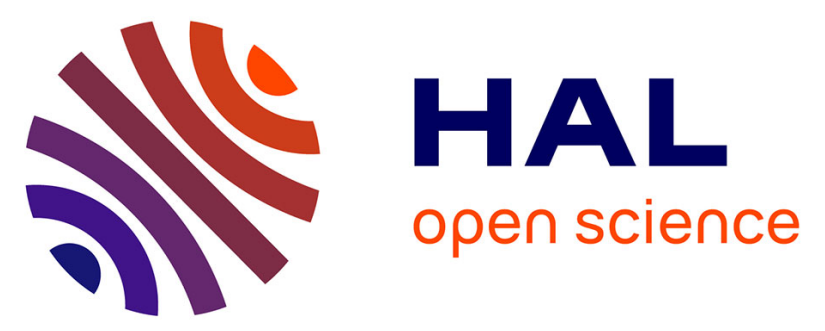

\title{
Monitoring and flux determination of trace metals in rivers of the Seversky Donets basin (Ukraine) using DGT passive samplers
}

\author{
Yuliya Vystavna, Frédéric Huneau, Mikael Motelica-Heino, Philippe Le
} Coustumer, Yuri Vergeles, Felix Stolberg

\section{To cite this version:}

Yuliya Vystavna, Frédéric Huneau, Mikael Motelica-Heino, Philippe Le Coustumer, Yuri Vergeles, et al.. Monitoring and flux determination of trace metals in rivers of the Seversky Donets basin (Ukraine) using DGT passive samplers. Environmental Earth Sciences, 2012, 65, pp.1715-1725. 10.1007/s12665011-1151-4 . insu-00606663

\section{HAL Id: insu-00606663 \\ https://hal-insu.archives-ouvertes.fr/insu-00606663}

Submitted on 7 Jan 2014

HAL is a multi-disciplinary open access archive for the deposit and dissemination of scientific research documents, whether they are published or not. The documents may come from teaching and research institutions in France or abroad, or from public or private research centers.
L'archive ouverte pluridisciplinaire HAL, est destinée au dépôt et à la diffusion de documents scientifiques de niveau recherche, publiés ou non, émanant des établissements d'enseignement et de recherche français ou étrangers, des laboratoires publics ou privés. 


\section{Monitoring and flux determination of trace metals in rivers of the}

\section{Seversky Donets basin (Ukraine) using DGT passive samplers}

Yuliya VYSTAVNA ${ }^{1,2}$, Frédéric HUNEAU ${ }^{1}$, Mikael MOTELICA-HEINO ${ }^{3}$, Philippe LE COUSTUMER $^{1}$, Yuri VERGELES ${ }^{2}$, Felix STOLBERG $^{2}$

${ }^{1}$ Université de Bordeaux, GHYMAC Géosciences Hydrosciences, B18 avenue des Facultés, 33405 Talence, France

${ }^{2}$ National Academy of Municipal Economy at Kharkiv, Department of Environmental Engineering and Management, vul. Revolutsii 12, Kharkiv, 61002, Ukraine

${ }^{3}$ Université d'Orléans, CNRS/INSU Institut des Sciences de la Terre d'Orléans, UMR 6113 Campus Géosciences 1A, rue de la Férollerie 41071 Orléans cedex 2, France

\section{Corresponding author:}

Dr. Frédéric HUNEAU, Université de Bordeaux, GHYMAC Géosciences Hydrosciences, B18 avenue des Facultés, 33405 Talence, France

Tel: +33.5.40.00.88.41 ; Fax: +33.5.40.00.31.13 ; frederic.huneau@u-bordeaux1.fr 


\section{Abstract}

This paper reports the results of the in situ application of diffusive gradients in thin-films (DGT) passive samplers for trace metals $(\mathrm{Cd}, \mathrm{Co}, \mathrm{Cr}, \mathrm{Cu}, \mathrm{Ni}, \mathrm{Pb}$ and $\mathrm{Zn})$ monitoring in transboundary Udy and Lopan rivers of the Seversky Donets watershed in the Kharkiv region,Ukraine, which has a long history of industrial development. The research discusses potential sources of DGTmeasured labile metals in water and seasonal variations. Also, our results demonstrate the performance of using DGT to identify and to measure labile metal concentrations in contrasted climate conditions (cold snowy winter and hot summer) and appropriateness of such a tool for continuous water monitoring with the presence of an ice cover. Results show that DGT-measured concentrations of most of trace metals were much higher downstream of the wastewater treatment plants discharges than upstream; thus wastewater treatment plants seem not able to reduce or to remove the trace metals contaminations and become major sources of studied pollutants in the studied rivers. The calculation of the average metal fluxes to base on the DGTmeasured concentrations confirmed that urban wastewater discharges significantly contribute to the metal fluxes into the Udy and the Lopan rivers during both low-flow and high-flow periods. Compared to the wastewaters inputs in the rivers, the transboundary effect is limited, but should also be taken into account as the origin of some metals is from sources located on the adjacent Russian territory.

Keywords: Passive Samplers, DGT, Trace Metals, Transboundary Rivers, Water Treatment Plant, Seasonal Variation, Eastern Europe 


\section{Introduction}

Ukraine is one of the post-soviet East European countries (46,08 million inhabitants by 2009) with a long history of large-scale industrial and agricultural activity. It borders Romania, Slovakia, Poland, Russia, Belarus and Moldova and shares transboundary watersheds with these countries. Earlier studies on the contamination of water bodies in the eastern part of Ukraine (Linnik, 2003; Vasenko et al, 2006) showed that concentrations of $\mathrm{Cu}, \mathrm{Zn}, \mathrm{Cr}$, and $\mathrm{Pb}$ are not in the agreement with national water quality standards (GCPL, 1991; SNPL, 1991) (Table 1). These investigations concluded that the main sources of metals are transboundary effluents, discharges of treated wastewaters and run-off from urban and agricultural areas.

In spite of the importance of the evaluation of the metal contamination in natural waters, the monitoring of these elements in Ukraine is not regular and yet insufficient. Limiting factors for an adequate water monitoring are the lack of equipment and financing for research laboratories and environmental control authorities (e.g. the Ministry of Environmental Protection). The number of sampling sites is usually limited to just two or three per river and only rivers receiving effluents from wastewater treatment plants are monitored. The water monitoring laboratories in Ukraine use mostly grab methods of sampling, which do not take into account influences (e.g. changes in hydrologic conditions and/or pollutants inputs). Moreover only the total concentrations of metals are determined, no evaluation of other metals forms and metals bioavailability is conducted. Thus, there is a lack of data on the presence of labile metals in rivers of industrial areas of Ukraine, whereas it is well-known that they play a crucial role in the bioaccumulation and eco-toxicity in living organisms (Alfaro-De la Torre et al, 2000; Janssen et al, 2003).

In order to improve the knowledge on labile metals concentrations and fluxes of this metal form in rivers of industrial and urbanized areas of Ukraine, in situ water sampling was undertaken using the passive sampling technique as diffusive gradients in thin-films (DGT) technique. This passive sensor tool was developed about 20 years ago at Lancaster University for the integrative 
sampling and measurement of dissolved labile metals. It bases on the diffusion of metals through a hydrogel layer of a certain thickness to a binding phase where they are concentrated (Buffle and Horvai, 2000; Zhang and Davison, 2000; Motelica-Heino et al, 2003). DGT samplers have been increasingly used for measuring labile metal concentrations in the aquatic environment, soils and sediments (Meylan et al, 2004; Buzier at al, 2006; Dunn et al, 2007; Roulier et al, 2008; Schintu, et al., 2008). The DGT technique demonstrates simplicity of deployment and retrieval during the field procedures, minimum sample handling between installation and analysis and easy storage (Denney et al, 1999). Compared to grab sampling and subsequent laboratory analysis of spot samples, DGT are used without additional reagents, energy sources and DGTmeasurements are able to reduce the risk of uncontrolled changes that can occur during the sampling, storage or treatment (Alfaro-De la Torre et al, 2000). Because of the pre-concentration capability of DGT that integrates temporal variations in the sampled media; lower metal concentrations can be measured in water in contrast to grab sampling. This integrating property helps to take into account different pollution events (run-off, random wastewaters discharge and etc) even if the sampling frequency is not high enough.

Other important point is that DGT shows very positive results while used in various climate conditions. There are in fact evidences of successful application of the DGT technique from subtropics (Denney et al, 1999; Dunn et al, 2003) to the polar environments (Larner et al, 2006; Stark et al, 2006). This is an important issue for the utilisation of these sensors in very continental regions with hot dry summer and cold snowy winter, despite potential problems with highly diluted waters (ionic strength lower than $2 \times 10-4 \mathrm{M}$ ) (Alfaro-De la Torre et al, 2000). With adequate detection limits and accuracy, the technique suites to the monitoring of labile metals in various aquatic environments such as coastal and seawaters (Australian seawaters: Munksgaard and Parry, 2003), rivers (Sava River, Croatia: Dragun et al, 2008) and lakes (5 lakes in England: Gimpel et al, 2003). 
This paper discusses the presence of priority trace metals as $\mathrm{Cd}, \mathrm{Cu}, \mathrm{Cr}, \mathrm{Pb}, \mathrm{Ni}$ and $\mathrm{Pb}$, but also the potentially toxic metal as Co in labile forms in the Udy and Lopan rivers of industrial and urbanised the Kharkiv region, Ukraine, the origin and fluxes of labile trace metal forms in the studied water bodies, seasonal variations in metal concentrations and whether these metals are problematic for the long-term exploitation of transboundary water resources according to the water regulation standards.

\section{Methods}

\subsection{Sampling area}

Deployment of DGT samplers was conducted in the Lopan and Udy rivers of the Kharkiv region (Eastern part of Ukraine) during August 2008 and January 2009. These alluvial transboundary rivers are extensively used for recreation activities, drinking water supply, irrigation and fishing in the Belgorod region of Russia and the Kharkiv region of Ukraine (about 4,500,000 inhabitants totally in both regions). Major anthropogenic factors able to impact on these water bodies are associated with the long-term industrial and municipal water supply, as well as discharges of wastewaters (Vasenko et al, 2006).

The Kharkiv region is one of the largest industrial regions in Ukraine, with a population of ca. 3 million (2009). During the soviet times (1919-1990), an extensive industrial development took place in the region featuring military production, machinery, mechanical, electrical, chemical and radio-electronic engineering. This region is characterized by a relative scarcity and an uneven distribution of available resources of freshwater. Regional water supply for the household and industries is mostly coming from surface water sources ( $85 \%$ of the total consumption). The Udy and Lopan rivers, with a total catchment area in Ukraine of about $3460 \mathrm{~km}^{2}$, along which the city of Kharkiv is located (Figure 1) have their sources in the Forest-Steppe natural zone of the southern slopes of the Mid-Russian rolling plane. Soils of the region are represented by grassland chernozems and grey forest types. The duration of winter is about 125 to 130 days, and the warm 
period is about 118 to 200 days per year. The coldest month is January (average temperature of $7.1^{\circ} \mathrm{C}$ ), and the warmest is July (average temperature of $+20.5^{\circ} \mathrm{C}$ ). The mean annual temperature is around $7.6{ }^{\circ} \mathrm{C}$ and rainfall amount varies between 470 and $540 \mathrm{~mm}$ per year (Jakovlev et al, 2002).

The total length of the Udy River is $164 \mathrm{~km}$ and its tributary, the Lopan River, is about $98 \mathrm{~km}$ long. The river depth ranges from 0.4 to $2.3 \mathrm{~m}$ and their flows are regulated by several dams constructed along the watercourses. The mean annual discharge of the Lopan River is $1.4 \mathrm{~m}^{3} \mathrm{~s}^{-1}$ in winter and $0.9 \mathrm{~m}^{3} \mathrm{~s}^{-1}$ in summer whereas the discharge of the Udy River is $6.8 \mathrm{~m}^{3} \mathrm{~s}^{-1}$ and $2.5 \mathrm{~m}^{3} \mathrm{~s}^{-1}$, respectively. Rivers are partly covered by ice from the end of November to the end of March. The subsurface geological structures of the catchment area are dated from Palaeogene and consist mainly of sedimentary rocks like sandstone, marl and chalk. The major land use categories on the watershed are agriculture (40\%), urban lands $(50 \%)$ and water reservoirs $(10 \%)$.

Both rivers are still impacted by metal inputs from urban and agricultural origin despite the significant decrease of production activities after the collapse of the Soviet Union; in fact the water quality has not improved since (NRDW, 2006). These rivers receive the most of the municipal and industrial wastewaters (about $1,000,000 \mathrm{~m}^{3}$ per day). Wastewaters are discharged into the same river basins, which are used for water supply, thus the aquatic pollution has a strong impact on the sanitary conditions and on the health of the population (NRDW, 2006).

\subsection{River water sampling}

Four sites on the Udy River and four sites on the Lopan River were selected with special attention to the potential pressure points on the watercourses, like sewage treatment plants, landfill sites or inputs from industries and the urban areas themselves (Figure 1). DGT samplers with a $0.4 \mathrm{~mm}$ resin gel layer, a $0.8 \mathrm{~mm}$ diffusive gel layer and a $0.45 \mu \mathrm{m}$ pore-size filter were purchased from DGT Research Ltd. (Lancaster, UK). In August 2008 and January 2009, DGT 
probes were deployed at selected sampling sites for a period from 15 to 30 days. The duration of DGT-samplers exposure was chosen based on the low flow (July-August) and the high flow (January-February) data in order to compare two extreme periods of the hydrological cycle.

Probes were exposed using a fishing line and attached at a depth of $0.20-0.25 \mathrm{~m}$ to avoid turbulent flow zones. During the winter campaign, samplers were installed at a depth of $0.15 \mathrm{~m}$ below the ice-layer, the thickness of which varied from 0.05 to $0.20 \mathrm{~m}$. For stations all stations duplicate DGT probes were installed to allow the estimation of the reproducibility of the measurements and intra-site variation. In order to prevent the contamination of DGT by trace elements from the air, the probes were open from the plastic protection at sampling sites and installed immediately in the water. After the retrieval the DGT were therewith packed in the plastic protection. The DGT probes were stored before the analysis at a temperature of $4{ }^{\circ} \mathrm{C}$ in plastic bags and in humid conditions (a few drops of distilled water were added to allow some moisture).

Two DGT probes were used as blanks i.e. were only exposed to air in the laboratory but not set in the water. Water temperature, $\mathrm{pH}$ and conductivity were measured in situ with a WTW ${ }^{\odot}$ Multiline P4 meter. The water temperature at sampling points ranged between 19.0 and $25.0^{\circ} \mathrm{C}$ during the summer and between 2.0 and $7.0^{\circ} \mathrm{C}$ during the winter sampling campaigns. Conductivity varied from 1010 to $1360 \mu \mathrm{Scm}^{-1}$ and $\mathrm{pH}$ from 6.8 to 7.9 . Total organic carbon (TOC) was determined from spot unfiltered samples during the summer campaign only and measured by TOC-5000, Schimadzu ${ }^{\odot}$ automated analyzer following ISO 10694. Physicochemical parameters of the Udy and Lopan rivers for both campaigns are reported in Table 2.

\subsection{DGT retrieval and data interpretation}

Elution of metals from the binding phase of the DGT probes $\left(3.14 \mathrm{~cm}^{2}\right)$ was carried out by immersion in $1 \mathrm{~mL}$ of $1 \mathrm{M} \mathrm{HNO}_{3}$ (Supra-pure, Merck, Darmstadt, Germany) for 48 hours (Zhang and Davidson, 2000) in the laboratory and then diluted to $10 \mathrm{ml}$ with $\mathrm{HNO}_{3} 2 \%$. Milli-Q water (Millipore, UK) was used to prepare all samples. Analyses of trace metals $(\mathrm{Cd}, \mathrm{Co}, \mathrm{Cr}, \mathrm{Cu}, \mathrm{Ni}$, 
$\mathrm{Pb}$ and $\mathrm{Zn}$ ) in the eluted samples were performed with the use of a PQ3 (VG, Manchester, UK) ICP-MS at the French Geological Survey (BRGM) in Orléans according to the European standard NF EN ISO 5667-3. The limits of detections are presented in Table 3.

The concentrations of each metal determined by DGT $\left(\mathrm{C}_{\mathrm{DGT}}\right)$ were then calculated using the temperature dependent diffusion coefficient (1):

$$
C_{D G T}=M \cdot \Delta g /(D \cdot t \cdot A)(1)
$$

where $\Delta g$ is the thickness of the diffusive gel $(0.8 \mathrm{~mm})$ plus the thickness of the filter membrane $(0.13 \mathrm{~mm}), D$ the diffusion coefficient of metal in the gel, $t$ deployment time and $A$ the exposure area $\left(A=3.14 \mathrm{~cm}^{2}\right)$ (Zhang and Davison, 1995; DGT Research, 2002).

The mass of metal in the resin gel (M) was obtained using the following equation (2):

$$
M=C e\left(V_{H N O 3}+V g e l\right) / f e
$$

where $\mathrm{Ce}$ is the concentration of metals in the $1 \mathrm{M} \mathrm{HNO}_{3}$ eluting solvent $\left(\mu \mathrm{g} \mathrm{L}^{-1}\right), V_{H N O 3}$ the volume of $\mathrm{HNO}_{3}$ added to the resin gel, $\mathrm{Vgel}$ the volume of the resin gel, equal to $0.16 \mathrm{~mL}$, and $f e$ the elution factor is equal to 0.8 for all metals as given by the manufacturer. $\mathrm{C}_{\mathrm{DGT}}$ corresponds to the interpreted concentration of the water sample and is a time-averaged concentration over the time of the probe deployment. Similarly analytical detection limits in terms of $\mathrm{C}_{\text {DGT }}$ were calculated from the ICP-MS detection limits and blank values were determined from the DGT blank probes. Additionally field detection limits used in this study were calculated as 3 times the standard deviation of the field blank concentrations. Blank values and detection limits are reported in Table 3.

\subsection{Trace metal fluxes determination}

In order to determine the influence of potential metal sources, labile metal fluxes were calculated using the following equation (Warnken and Santschi, 2009) based on the flow corresponding to the period for which the samples were deployed:

$$
F_{M e}=Q \cdot C \cdot 8.6410^{-2} \text {, }
$$


where $F_{M e}$ is daily flux of trace metal, $\mathrm{kg} \mathrm{d}^{-1}, Q$ the mean water flow rate, $\mathrm{m}^{3} \mathrm{~s}^{-1}, C$ is the mean concentration of trace metal, $\mu \mathrm{g} \mathrm{L}^{-1}$, measured by DGT (blank substracted) and the coefficient $8.6410^{-2}$ is for the transformation of data in $\mathrm{kg} \mathrm{d}^{-1}$.

\section{Results and discussion}

\subsection{Performance of the DGT use}

The results obtained after the deployment of DGT in contrasting climate conditions confirmed the possibility of using these passive techniques for sampling under the river ice cover during winter. Taking into account the difficulties of grab water sampling on icy river sites as present approach needs to make numerous holes for the time and space integrative water sampling, the DGT can be proposed to simplify the sampling procedure, save energy and man power. Concerning the accuracy of the analysis, the detection limits are indentified as lower during the summer period than during the winter, as shown in Table 3 and Table 4 . In this case, the interpretation of the data depends on the diffusion coefficient values of which vary with the water temperature and possibly impact on the data determination. As regards to other contrasted influences, earlier reported results showed minor impact of the water flow on the DGT measurements (Gimpel et al, 2003). The determination of the total dissolved concentration of highly complexed metals (e.g. $\mathrm{Cu}$ ) by DGT could be underestimated as metal speciation directly affects the DGT measurements and hereby DGT measures the labile metal species only (Warnken et al, 2007).

\subsection{Trace metals and potential sources}

The DGT-measured concentrations (blank substracted) are presented in Table 5 and show significant spatial variability along both watercourses. Trace metal composition patterns and concentrations appeared different in the two rivers, however, in both cases average concentrations decreased in the following order $\mathrm{Zn}>\mathrm{Ni}>\mathrm{Cu}>\mathrm{Cr}>\mathrm{Co}>\mathrm{Cd}>\mathrm{Pb}$. 
In the Lopan River, maximum concentrations of $\mathrm{Co}, \mathrm{Cr}, \mathrm{Ni}, \mathrm{Zn}$, and $\mathrm{Pb}$ were found downstream of the wastewater discharges (site L09), both in summer and winter. During winter sampling the maximum concentrations of $\mathrm{Cd}$ and $\mathrm{Cu}$ were found downstream of the wastewater discharges, and in summer the maximum of $\mathrm{Cd}$ was measured at the sampling site located next to the border with Russia (site L01), and the maximum of $\mathrm{Cu}$ was obtained from the sampling site at the very centre of the city (site L06).

In the Udy River, the highest concentrations of $\mathrm{Cd}, \mathrm{Cu}, \mathrm{Ni}$, and $\mathrm{Pb}$ were measured downstream of the wastewater discharge (site U07) for both seasons. The maximum concentrations of $\mathrm{Co}, \mathrm{Cr}$, and $\mathrm{Zn}$ in winter period were found in $\mathrm{U} 07$, as well, and the maximum level of $\mathrm{Cr}$ and $\mathrm{Zn}$ in August 2008 was observed in sites located close to the border with Russia (U01 and U02). Only the DGT-measured concentrations of Zn during summer in sampling sites U01 and U02 were even higher than the total metal concentrations permitted by the Ukrainian water quality standards for the fishery water use category (GCPL, 1991). In comparison with previous study on trace metals in the Udy and Lopan River (Vasenko et al, 2006), the value of DGT-measured concentrations of $\mathrm{Cu}, \mathrm{Cr}, \mathrm{Zn}$ and $\mathrm{Pb}$ were two orders of magnitude lower than the total metal concentrations (Table 1).

The calculation of labile metals fluxes (Figure 2) from the blank substracted DGT metal concentrations showed that the urban wastewater discharge is a significant source of $\mathrm{Cd}, \mathrm{Co}, \mathrm{Cu}$, $\mathrm{Cr}, \mathrm{Ni}, \mathrm{Pb}$ and $\mathrm{Zn}$ for both Lopan and Udy rivers. The presence of metals in the municipal wastewaters can be attributed to the galvanic industry wastewaters discharged into the municipal sewage system from local enterprises. The Kharkiv Wastewater Treatment Plant 'Dykanivskiy' (WWTP 'D' with a capacity of 700,000 $\mathrm{m}^{3} \mathrm{~d}^{-1}$ ) and 'Bezludivskiy' (WWTP 'B' with a capacity of $250,000 \mathrm{~m}^{3} \mathrm{~d}^{-1}$ ) both apply combined biological treatment for run-off and sewage consisting of mixed household ( $85 \%$ of total volume) and industrial (15\% of total volume) wastewaters. Before entering the municipal WWTP, galvanic wastewaters are only pre-treated by very basic industrial WWTP owned and managed by the industrials. In that case the insufficiently treated 
industrial wastewaters can enter the WWTP 'D' and WWTP 'B', what are not designed to cope with the reduction of the trace metals contamination in the water.

Organic matter can also influence on the mitigation of the bioavailability of metals resulting in the complexation of labile forms with organic particles (Tusseau-Vuillemin et al, 2007). The results show that the TOC contamination is decreasing in sites located downstream of wastewater discharges (Table 2), but further study should be done to evaluate the origin of the organic substances as it has an impact on the speciation of the metallic contaminants (Buzier et al, 2006b; Tusseau-Vuillemin et al, 2007).

\subsection{Seasonal variations of trace metals contamination}

Natural seasonal changes can influence the mobility of trace metals (Beck and Sanudo-Wilelmy, 2007; Arain et al, 2008). The dilution, complexation with ligands (Sangi et al, 2002; Tusseau Vuillemin et al, 2007; Balistrieri and Blank, 2008), sorption by particles (Linnik, 2003; Baalousha et al, 2005, 2006a and 2006b; Buzier et al, 2006a), bioaccumulation (Alfaro-De la Torre et al, 2000; Meylan et al, 2004) depend on temperature (Beck and Sanudo-Wilelmy, 2007), precipitation (Aung et al, 2008) water chemistry (Dahlqvist et al, 2007; Pernet-Coudrier et al, 2008) and ionic strength of the solution (Baalousha et al, 2006a; Baalousha et al, 2006b). Additionally, labile forms of metals can be released from sediments which can also contain a significant amount of absorbed elements (Vystavna et al, 2008). These factors have seasonal patterns too.

Our results showed that the summer contents of all metals at the sampling point U07 (located on the Udy River downstream of the Lopan River influence and municipal wastewaters discharge) are increasing comparing to site L09 (where the Lopan River receives wastewaters from WWTP 'D'). The variation of DGT averaged metal fluxes can attributed to temporal changes of metals discharge with wastewaters, effluents from other sources (run-off etc.), remobilization of additional labile forms from the river sediments that can be caused by high water temperature 
and low dissolved oxygen (Beck and Sanudo-Wilhelmy, 2007). Further research on the sediments quality of the Lopan and Udy rivers is foreseen to evaluate the contamination of metals in this media and processes of the water-sediments interaction.

In contrast to the summer season, winter DGT-measured concentrations of metals in U07 are decreasing compared to L09 as a likely combined effect of better dilution with a high water flow (due to increased precipitation inputs) and a lower water temperature. For comparison, the rate of the wastewater effluent to the river flow in summer is $22: 1$, whilst in winter such a ratio is $5: 1$. In contrast, results of metals fluxes calculation show that the amounts of all measured metals in the Lopan River during the winter were higher than in the summer in the site L09 (Figures 2). This is connected with seasonal variations in the economic activity of companies and municipal water users.

Additionally, correlations in spatial and seasonal patterns were found for almost all pairs of DGT-measured concentrations of metals for the winter season (Table 6). In contrast, for the summer season a good agreement was observed only for the $\mathrm{Cr}-\mathrm{Pb}$ (Pearson's criterion, $\mathrm{r}=0.9023, \mathrm{a}<0.05, \mathrm{n}=20$ ). The differences can be explained with changes in metals behaviour in cold high-flow and hot low-flow periods (Beck and Sanudo-Wilhelmy, 2007). Also these strong correlations between elements indicate that they have similar sources, maybe related to a few dominant inputs during the winter. The relationship between winter and summer seasons shows, that a strongest positive correlation was recorded in the Udy River for $\mathrm{Cd}(\mathrm{r}=0.92), \mathrm{Ni}$ $(\mathrm{r}=0.99)$ and $\mathrm{Pb}(\mathrm{r}=0.70)$ and in the Lopan River for $\mathrm{Cr}(\mathrm{r}=0.87), \mathrm{Ni}(\mathrm{r}=0.96), \mathrm{Pb}(\mathrm{r}=0.95)$ and $\mathrm{Zn}(\mathrm{r}=0.83)$. Such seasonal behaviour can be explained by the continuous release of these metals which only slightly depends on seasons; the pedogenic origin of these elements can also be called for especially for $\mathrm{Ni}$ and $\mathrm{Pb}$. Some negative correlations were found for $\mathrm{Zn}$ in the $\mathrm{Udy}$ River $(r=-0.50)$ and $\mathrm{Cd}$ in the Lopan River $(r=-0.35)$, indicating the influences of different sources on the water chemistry during summer and winter. In summer, $\mathrm{Zn}$ can enter the river through run-off contaminated by agricultural activities using Zn-rich pesticides. Additionally, the 
comparison of the two rivers pointed out, that the correlation of $\mathrm{Zn}$ in August was estimated as negative $(r=-0.35)$, which demonstrates a different origin of pollution sources, while correlations in January have a very high level $(r=0.99)$.

Seasonal significant differences (Standard deviation, S.D. > 5) were observed in concentrations of $\mathrm{Cu}, \mathrm{Ni}$ and $\mathrm{Zn}$ in both rivers. The higher mean concentrations of $\mathrm{Cu}, \mathrm{Ni}$ and $\mathrm{Zn}$ in the Udy River were found in August, then $\mathrm{Cu}$ and $\mathrm{Ni}$ correlate positively with water conductivity $(\mathrm{r}=0.89$ and $\mathrm{r}=0.80), \mathrm{Zn}$ correlates positively with $\mathrm{pH}(\mathrm{r}=0.65)$. In the Lopan River, $\mathrm{Cu}, \mathrm{Ni}$ and $\mathrm{Zn}$ show a negative correlation with the water conductivity $(\mathrm{r}=-0.61, \mathrm{r}=-0.31$ and $\mathrm{r}=-0.4$ respectively), but a positive correlation exists for $\mathrm{Cu}$ and $\mathrm{Zn}$ with the $\mathrm{pH}(\mathrm{r}=0.62$ and $\mathrm{r}=0.45)$ in January. These results indicate that other factors such as $\mathrm{pH}$ and conductivity can be responsible for the remobilization of the bioavailable forms of metals in the water and cause secondary water pollution (Caruso and Bishop, 2009) depending on seasonal variations.

\subsection{Transboundary issues}

It was also found that the concentrations of Cd and Co in the upper Lopan River (L01) and Cd, $\mathrm{Cr}$ and $\mathrm{Zn}$ in the upper Udy River (U01) are significantly higher than downstream-located sampling sites (Table 5). Since both sampling sites are located near the border with Russia, we can assume that certain transboundary upstream influences on the water quality are taking place. It is difficult yet to identify and to evaluate the sources of metals in the neighbouring Belgorod region, Russia. There are no visible and reported industrial activities upstream of U01 and L01 on the Ukrainian part and no any referent data on the background of rivers sources were found. Downstream from the border with Russia and before entering the Kharkiv urban area (L03) contents of $\mathrm{Cd}$ in the Lopan River are much lower because of dilution processes. Similar patterns were also observed for $\mathrm{Pb}$ in the Udy River and $\mathrm{Co}$ in the Lopan River.

The Belgorod region (Russia), where the Lopan and the Udy Rivers have their sources, is a district of the territory of the Kursk Magnetic Anomaly (KMA) with very well developed mining 
activities and iron ore-processing industry, metallurgical plants and at the same time with an important agricultural activity (Samarina, 2008). The results of researches carried out by Samarina $(2003,2007,2008)$ show that the rivers of the Belgorod region are directly affected by the mining and smelting works and confirm the anthropogenic origin of $\mathrm{Cr}, \mathrm{Cu}, \mathrm{Ni}, \mathrm{Pb}$ and $\mathrm{Zn}$ in the Oskol River (main tributary of the Seversky Donets River). Unfortunately, Samarina (2003, 2007, 2008) did not study Cd and Co, but other works have already demonstrated that high concentration of $\mathrm{Cd}$ and Co are connected with mining activities (Jordao et al, 1999; Kim et al, 2007) but it should be kept in mind that the transboundary pollution is limited compared to urban or wastewater derived pollution.

\section{Conclusions}

Our results demonstrate that the DGT technique can be applied to measure the water contamination by labile trace metals both in hot summer low-flow and cold snowy winter highflow periods. This method appeared more convenient than the grab method of sampling, as it does not demand the collection of numerous samples for the estimation of time-weighted average concentrations of trace elements, especially in cold weather conditions (it does not require the drilling of many holes through the ice cover) and can be recommended for the continuous water monitoring of bioavailable forms of priority trace metals.

This first application of the DGT technique in Ukraine improved the knowledge on the labile trace metals contamination in one of the most industrialised region of the country and helped to point out the principal sources of metals in the rivers. Elements such as $\mathrm{Cd}, \mathrm{Co}, \mathrm{Cr}, \mathrm{Cu}, \mathrm{Ni}, \mathrm{Pb}$ and $\mathrm{Zn}$ were found in most of the samples. The concentrations and fluxes of DGT-measured trace metals were much higher downstream of the wastewater treatment plant discharges compared to upstream. However, in locations close to the border with Russia, the concentration of $\mathrm{Zn}$ in the Udy River in summer exceeded the Water Quality Standards of Ukraine. Remarkably high contents of $\mathrm{Cr}$ and $\mathrm{Cd}$ were observed in the sampling sites next to the border 
with Russia that probably reflects the transboundary upstream influences on the water quality and needs further research focus.

The concentration in trace metals in the water displayed a seasonal variation pattern. The anthropogenic inputs (wastewater discharges) affect the trace metal concentrations in a strong manner during the low flow summer period while increased flow conditions during the cold season provide a better dilution of pollutants.

Fluxes of metals during the hot low-flow summer period were lower compared to the cold highflow winter period. This indicates that the metal release is continuous and at the same time seasonally variable depending on both natural and socio-economic conditions in the studied region.

Thus, this passive sampling technique can be used for the long-term water monitoring during various climatic conditions conducted by regional environmental and water authorities of Ukraine. In a further step the data gathered during this study will be used to model the water pollution processes considering many socio-economic indicators (demography, employment structure, economic structure, infrastructure, ...) and changes in the hydrological conditions (Chichurin and Vystavna, 2009). Such a tool (Vystavna, 2005) is now necessary to be developed in order to be able to forecast the water quality evolution in relation with the socio-economic dynamic of the region.

\section{Acknowledgements}

This research was conducted in the frameworks of the International Collaborative Programme “Partenariat Hubert Curien DNIPRO” (Grant N 19744VJ 2009/2010) with the financial support from both French Ministry of Foreign Affairs and Ukrainian Ministry of Education and Science. Some authors have been granted by the European Union through the ERASMUS MUNDUS External Cooperation Window Programme (Lot 6/7 - Belarus, Moldova, and Ukraine). The authors would like to thank Dr Michel Mench from the Université de Bordeaux (UMR 
BIOGECO INRA 1202) for valuable comments provided during the manuscript preparation and Aliaksandr Kolbas for technical assistance. 


\section{References:}

Alfaro-De la Torre, M.C., Beaulieu, P.-Y., Tessier, A., 2000. In situ measurement of trace metals in lake water using the dialysis and DGT techniques. Anal Chem Acta 418, 53-68.

Arain M.B., Kazi T.G., Jamali M. K., Jalbani N., Afridi H.I., Shach A., 2008. Total dissolved and bioavailable elements in water and sediment samples and their accumulation in Oreochromis mossambicus of polluted Manshar Lake. Chemosphere 70, 1845-1856.

Aung N. N., Nakajima F., Furumai H., 2008. Trace metal speciation during dry and wet weather flows in the Tama River, Japan, by using diffusive gradients in thin films (DGT). $J$. Environ. Monit.10, 219-230.

Baalousha M., Kammer F. V. D, Motelica-Heino, M., Le Coustumer P., 2005. 3D Characterization of natural colloids by FIFFF-MALLS-TEM. Anal. Bioanal. Chemistry $383,549-554$.

Baalousha M., Kammer F. V. D., Motelica-Heino, M.; Baborowski, M., Hofmeister, C.; Le Coustumer, P., 2006a. Size-based speciation of natural colloidal particles by flow fieldflow fractionation, inductively coupled plasma-mass spectroscopy, and transmission electron microscopy/ X-ray energy dispersive spectroscopy: colloids-trace element interaction. Environ. Sci. Technol. 40, 2156-2162.

Baalousha, M., Motelica-Heino, M.,Coustumer, P. L., 2006b, Conformation and size of humic substances : Effects of major cation concentration and type, $\mathrm{pH}$, salinity and residence time, Colloids and Surfaces A: Physicochemical and Engineering aspects 272 (1), 4855.

Balistrieri L. S., Blank R. G., 2008. Dissolved and labile concentrations of $\mathrm{Cd}, \mathrm{Cu}, \mathrm{Pb}$ and $\mathrm{Zn}$ in the South Fork Coeur d'Alene River, Idaho: Comparisons among chemical equilibrium models and implications for biotic ligand models. Applied Geochemistry 23, 3355-3371. 
Beck A. J., Sanudo-Wilhelmy S. A., 2007. Impact of water temperature and dissolved oxygen on copper cycling in an urban estuary. Environ. Sci. Technol. 41, 6103-6108.

Buffle, J., Horvai, G., 2000. General concepts. In: Buffle, J., Horvai, G. (Eds.), In Situ Monitoring of Aquatic Systems: Chemical Analysis and Speciation. John Wiley \& Sons Ltd, USA, pp.1-17.

Buzier, R., Tusseau-Vuillemin, M.-H., Marin dit Meriadec, C., Rousselot, O., Mouchel, J.-M., 2006a. Trace metal speciation and fluxes within a major French wastewater treatment plant: Impact of the successive treatments stages. Chemosphere 65, 2419-2426.

Buzier, R., Tusseau-Vuillemin, M.-H., Mouchel, J.M., 2006b. Evaluation of DGT as a metal speciation tool in wastewater. Sci. Total Env, 358, 277-285.

Caruso, B. S., Bishop M., 2009. Seasonal and spatial variation of metal loads from natural flows in the upper tenmile greek watershed, Montana. Mine Water Environ. DOI 10.1007/s10230-009-0073-9 (Article in press).

Chichurin A., Vystavna Y. Y., 2009. Mathematical Modeling of the River Pollution by Emergent Pollutants. Computer Algebra Systems in Teaching and Research. Mathematical Physics and Modeling in Economics, Finance and Education. Proceeding of the Workshop CASTR'2009. Published by the College of Finance and Management (Siedlce, Poland), 26-30.

Dahlqvist, R., Andersson , K., Ingri, J., Larsson, T., Stolpe, B., Turner, D., 2007. Temporal variations of colloidal carrier phases and associated trace elements in a boreal river. Geochimica et Cosmochimica Acta 71, 5339-5354.

Denney, S., Sherwood, J., Leyden, J., 1999.In situ measurements of labile $\mathrm{Cu}, \mathrm{Cd}$ and $\mathrm{Mn}$ in river waters using DGT. Sci. Total Environ. 239, 71-80.

DGT Research, 2002. DGT for measurements in water, soils and sediments. DGT Research Ltd., Lancaster. 
Dragun, Z., Biserka, R., Vibor, R., 2008. The labile metal concentration in Sava River water assessed by diffusive gradients in thin film. Chemical Speciation and Bioavalability 20 (1), 33-46.

Dunn, R.J.K, Teasdale, P.R., Warnken, J., Jordan, M.A., Arthur, J.M., 2007. Evaluation of the in situ, time-integrated DGT technique by monitoring changes in heavy metals concentrations in estuarine waters. Environ.Pollut. 148, 213-220.

Dunn, R.J.K., Teasdale. P.R., Warnken J., Schleich R.R., 2003. Evaluation of the diffusive gradient in a thin film technique for monitoring trace metal concentrations in estuarine waters. Environ. Sci. Technol. 37 (12), 2794-2800.

Gimpel, J., Zhang, H., Davison, W., Edward, A., 2003. In situ trace metal speciation in lake surface waters using DGT, dialysis and filtration. Environ. Sci. Technol. 37, 137-146.

GCPL 1991: General code of permitted limits and presumable save levels of impacts of hazardous substances in the waters use for fishery (in Russian)

Jakovlev, V.V., Svirenko, L.P., Chebanov, O.Ju. \& Spirin, O.I., 2002. Rising Groundwater Levels in North-Eastern Ukraine: Hazardous Trends in Urban Areas. In: Current Problems of Hydrogeology in Urban Areas, Urban Agglomerates and Industrial Centres. /Eds. K.W.F. Howard \& R.F. Israfilov. - Dordrecht: Kluwer Acad. Publ. - P. 221-241 (NATO ARW Series).

Janssen C.R., Heijerick D.G., De Schamphelaere K.A.C., Allen H.E., 2003. Environmental risk assessment of metals: tools of incorporating bioavailabilty. Environ. International 28, 793-800.

Jordao, C.P., Pereira, J.L., Jham, G.N., Bellato, C.R., 1999. Distribution of heavy metals in environmental samples near smelters and mining areas in Brazil. Environ. Technol. 20 (5), 489-498. 
Kim, J.G., Ko, K.-S., Kim, T.H., Lee, G.H., Song, Y., Chon C.-M., Lee, J.-S., 2007. Effect of mining and geology on the chemistry of stream water and sediments in a small watershed. Geoscience Journal 11 (2), 175-183.

Larner, B., Seen, A. J., Snape, I., 2006. Evaluation of diffusive gradients in thin film (DGT) samplers for measuring contaminants in the Antarctic marine environment. Chemosphere 65, 811-820.

Linnik P. N., 2003. Complexation as the most important factor of in the fate and transport of heavy metals in Dnieper water bodies. Anal Bioanalytical Chemistry. 376, 405-412.

Meylan, S., Odzak, N., Behra, R., Sigg, L., 2004. Speciation of copper and zink in natural water freshwater: comparison of voltammetric measurements, diffusive gradient in thin films (DGT) and chemical equilibrium models. Analytica Chimica Acta 510, 91-100.

Motelica-Heino, M., Naylor, C., Zhang, H., Davison, W., 2003. Simultaneous release of metals and sulfide in lacustrine sediment. Environ. Sci. Techol 37 (19), 4374-4381.

Munksgaard, N.C., Parry, D.L., 2003. Monitoring of labile metals in turbid coastal seawater using diffusive gradient in thin film. J. Environ. Monit. 5, 145-149.

NRDW 2006: National Report on drinking water quality and supply in 2006 year. http://www.minjkg.gov.ua/editattach/bigdoc/nd_voda2006.doc (in Ukrainian)

Pernet-Coudrier, B., Clouzot, L., Varrault, G., Tusseau-Vuillemin, M. H., Verger, A., Mouchel, J.-M., 2008. Dissolved organic matter from treated effluent of a major wastewater treatment plant: characterization and influence on copper toxicity. Chemosphere 73, 593-599.

Roulier J.L., Tusseau- Vuillemin, M. H., Coquery M., Geffard O., Garric J., 2008. Measurement of dynamic mobilization of trace metals in sediments using DGT and comparison with bioaccumulation in Chironomus riparius : First application of an experimental study. Chemosphere 70, 925-932. 
Samarina, V.P., 2003. The effect of a mining and smelting plant on the dynamics of heavy metals in small river basins in the zone of Kursk-Belgorod Magnetic Anomaly. Water Resources, 30 (5), 596-604.

Samarina, V.P., 2007. Assessment of the impact of economic activity on the degree of overland flow contamination in the zone of the Kursk-Belgorod Magnetic Anomaly: Case study of the Oskol River. Water Resources 34 (5), 582-586.

Samarina, V.P., 2008. Effect of engineering-industrial activities in the region of the Kursk Magnetic Anomaly on the ecological state of the rivers waters. Geochemistry International, 46 (9), 998-1005.

Sangi M. R., Halstead M. J., Hunter K.A., 2002. Use of diffusion gradient thin film method to measure trace metals in fresh waters at low ionic strength. Analytica Chimica Acta, 456, 241-251.

Schintu, M., Durante, L., Maccioni, A., Meloni, P., Degetto, S., Contu, A., 2008. Measurement of environmental trace-metal levels in Mediterranean coastal areas with transplanted mussels and DGT techniques. Marine Pollut. Bull. 57, 832-837.

SNPL 1991: Sanitary norms of permitted limits of hazardous substances contents in the waters use for drinking and municipal water use (in Russian)

Stark, J.S., Johnstore, G.J., Palmer, A.S., Snape, I., Larner, B., Riddle, M.J., 2006. Monitoring the remediation of a near shore waste disposal site in Antarctica using the amphipod Paramoera walkeri and diffusive gradients in thin films (DGTs). Marine Pollut. Bul. 12 (52), 1595-1610.

Tusseau-Vuillemin, M.-H., Gourlay, C., Lorgeoux, C., Mouchel, J.-M., Buzier, R., Gilbin, R., 2007. Dissolved and bioavailable contaminants in the Seine River basin. Sci. Total. Env, $375(1-3), 244-256$.

Vasenko, O.G., Lungu, M.L., Iljevska, Y.A., Klymov, O.V. et al., 2006: Research report. The integrated field research of environmental conditions of water bodies of the Udy water 
basins (sub-basin of the Siverskiy Dinets River)/ "Rayder” Publ., Kharkiv, 156 p. (in Ukrainian).

Vystavna Y., 2005. The Balanced Model of the Sustainable Water Consumption in a Public Sector in Ukraine. Proceedings. Kalmar ECO-TECH'05. Conference on Waste to Energy, Bioremediation and Leachate Treatment. The Second Baltic Symposium on Environmental Chemistry, November 28-30, 2005 - Kalmar, Sweden, 455-461.

Vystavna Y., Le Coustumer P., Huneau F., Rakhmatullaev S., 2008. Impact of a municipal wastewater treatment plant on the quality of the sediments of the River Udy (Ukraine). UNESCO International Workshop on Erosion, Transport and Deposition of Sediments, Berne, Switzerland, 28-30 April 2008, book of abstracts, 106-107

Warnken, K.W., Santschi, P.H., 2009. Delivery of trace metals (Al, Fe, Mn, V, Co, Ni, Cu, CD, $\mathrm{Ag}, \mathrm{Pb}$ ) from the Trinity River watershed towards the ocean. Estuaries and Coasts 32, $158-172$.

Warnken, K.W., Zhang, H., Davison, W., 2007. In situ monitoring and dynamic speciation measurements in solution using DGT. In Greenwood, R., Mills, G., Vrana, B., (Eds.), Comprehensive Analytical Chemistry, Volume 48, Passive Sampling Techniques in Environmental Monitoring, Elsevier, pp. 251-278.

Zhang, H. and Davison, W., 1995. Performance characteristics of diffusive gradients in thin films for in situ measurement of trace metals in aqueous solution. Analitical. Chemistry. 67 (19), 3391-3400.

Zhang, H. and Davison, W., 2000. Direct In Situ Measurements of Labile Inorganic and Organically Bound Metal Species in Synthetic Solutions and Natural Waters Using DGT. Analitical. Chemistry. 72 (18), 4447-4457. 
Figure 1

Location of sampling sites

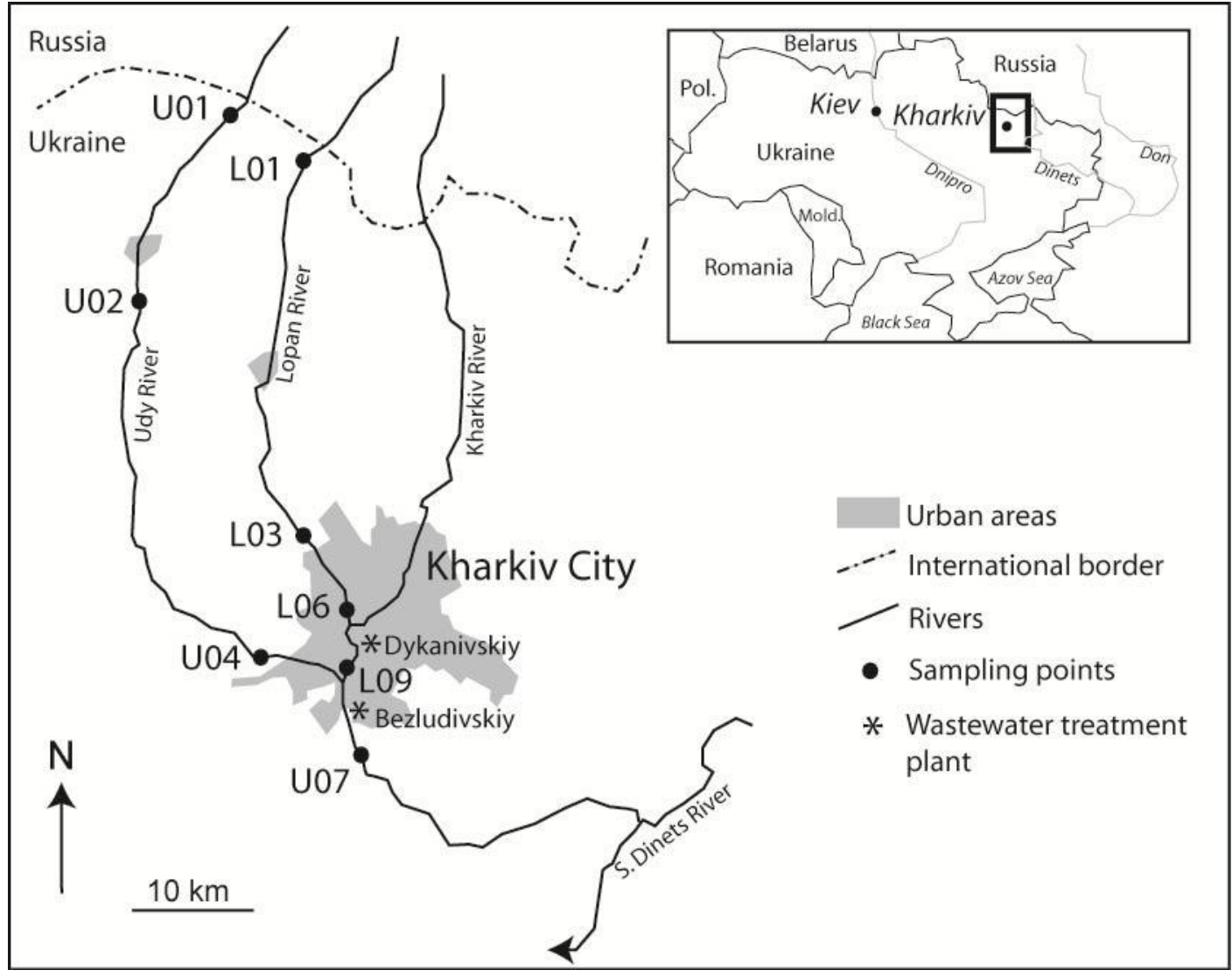




\section{Table list:}

Table 1. Total metals concentrations in the Udy and Lopan Rivers in the Kharkiv region, Ukraine in August 2005 determined by earlier study of Vasenko et al (2006), $\mu \mathrm{gL}^{-1}$

Table 2. Physico-chemical parameters of the Udy and Lopan Rivers in August 2008 and January 2009

Table 3. Precision of the analytical technique

Table 4. Calculated mean values ( $\mu \mathrm{g} \mathrm{L}^{-1}$ ), standard deviations (S.D. in $\mu \mathrm{g} \mathrm{L^{-1 }}$ ) and the relative standard deviations (rsd) of DGT-measured concentrations of metals in sites with replicated deployment

Table 5. Blank substracted DGT-measured concentrations of trace metals, $\mu \mathrm{g} \mathrm{L}{ }^{-1}$

Table 6. Correlations between spatial patterns of paired DGT-measured metal concentrations (Pearson's coefficient) 


\section{Figure list:}

Figure 1. Location of sampling sites

Figure 2. Average fluxes of trace metals in the Lopan River (L01-L09) and Udy River (U01U07) in August 2008 (white bar) and January 2009 (grey bar) 


\section{Table 1}

Total metals concentrations in the Udy and Lopan Rivers in the Kharkiv region, Ukraine in August 2005 determined by earlier study of Vasenko et al (2006), $\mu \mathrm{gL}^{-1}$

\begin{tabular}{|c|c|c|c|c|}
\hline Sampling site & $\mathrm{Cu}$ & $\mathrm{Zn}$ & $\mathrm{Cr}$ & $\mathrm{Pb}$ \\
\hline $\begin{array}{l}\text { Udy River - border with Russia (close to } \\
\text { U01) }\end{array}$ & $21 \pm 5$ & $59 \pm 15$ & $22 \pm 7$ & $<1$ \\
\hline $\begin{array}{l}\text { Udy River - downstream the Zolochiv } \\
\text { (close to U02) }\end{array}$ & $17 \pm 4$ & $58 \pm 15$ & $200 \pm 7$ & $2 \pm 1$ \\
\hline $\begin{array}{l}\text { Udy River, downstream the man-made } \\
\text { water reservoir (close to U03) }\end{array}$ & $34 \pm 1$ & $43 \pm 10$ & $13 \pm 4$ & $2 \pm 1$ \\
\hline $\begin{array}{l}\text { Udy River - upstream the Kharkiv city } \\
\text { (close to U04) }\end{array}$ & $10 \pm 3$ & $86 \pm 22$ & $28 \pm 9$ & $6 \pm 2$ \\
\hline $\begin{array}{l}\text { Udy River - upstream the wastewater } \\
\text { discharge }\end{array}$ & $13 \pm 4$ & $66 \pm 16$ & $34 \pm 11$ & $4 \pm 2$ \\
\hline $\begin{array}{l}\text { Udy River, downstream the wastewaters } \\
\text { discharge (close to U07) }\end{array}$ & $147 \pm 37$ & $111 \pm 28$ & $59 \pm 20$ & $41 \pm 14$ \\
\hline $\begin{array}{l}\text { Lopan River, downstream the wastewater } \\
\text { discharge (close to L09) }\end{array}$ & $92 \pm 23$ & $118 \pm 30$ & $17 \pm 6$ & $1 \pm 1$ \\
\hline $\mathrm{GCPL}^{1}, \mu \mathrm{gL}^{-1}$ & 5 & 10 & 1 & 0.2 \\
\hline $\mathrm{SNPL}^{2}, \mu \mathrm{gL} \mathrm{L}^{-1}$ & 1000 & 1000 & 50 & 30 \\
\hline
\end{tabular}

'- GCPL 1991: General code of the permitted limits and presumable save levels of impacts of hazardous substances in the waters used for fishery (in Russian)

2- SNPL 1991: Sanitary norms of the permitted limits of hazardous substances contents in the waters used for drinking and municipal water use (in Russian) 
Table 2

Physico-chemical parameters of the Udy and Lopan Rivers in August 2008 and January 2009

\begin{tabular}{|c|c|c|c|c|c|c|c|c|c|c|c|c|}
\hline & \multicolumn{2}{|c|}{$\begin{array}{c}\text { Temperature, } \\
{ }^{\circ} \mathrm{C}\end{array}$} & \multicolumn{2}{|c|}{ Velocity, $\mathrm{ms}^{-}$} & \multicolumn{2}{|c|}{$\mathrm{pH}$} & \multicolumn{2}{|c|}{$\begin{array}{c}\text { Conductivity, } \\
\mu \mathrm{Scm}^{-1}\end{array}$} & \multicolumn{2}{|c|}{$\mathrm{HCO}_{3}^{-}, \mathrm{mgL}^{-1}$} & \multicolumn{2}{|c|}{$\mathrm{TOC}, \mathrm{mgL}^{-1}$} \\
\hline & Aug & Jan & Aug & Jan & Aug & Jan & Aug & Jan & Aug & Jan & Aug & Jan \\
\hline L01 & 18 & 2 & 0.3 & 0.3 & 7.6 & 6.9 & 1030 & 1360 & 390 & 292 & 172.5 & nd* \\
\hline L03 & 18 & 2 & 0.07 & 0.07 & 7.5 & 7.3 & 1010 & 1250 & 451 & 296 & 69.79 & nd \\
\hline L06 & 22 & 2 & 0.1 & 0.1 & 6.9 & 7.6 & 1060 & 1130 & 414 & 385 & 133.4 & nd \\
\hline L09 & 20 & 7 & 0.3 & 0.3 & 7.1 & 7.5 & 1110 & 1200 & 390 & 364 & 50.79 & nd \\
\hline U01 & 19 & 2 & 0.05 & 0.05 & 7.3 & 6.8 & 844 & 1010 & 506 & 362 & 84.05 & nd \\
\hline U02 & 23 & 2.5 & 0.07 & 0.07 & 7.6 & 7.2 & 953 & 1160 & 445 & 301 & nd & nd \\
\hline U04 & 20 & 4 & 0.07 & 0.07 & 7.2 & 7.4 & 960 & 1240 & 427 & 331 & 63.81 & nd \\
\hline U07 & 20 & 8 & 0.17 & 0.17 & 7.4 & 7.3 & 1120 & 1280 & 451 & 339 & 51.57 & nd \\
\hline
\end{tabular}

*nd not determined 


\section{Table 3}

Precision of the analytical technique

\begin{tabular}{|l|c|c|c|c|c|c|c|}
\hline Sampling period & Cd & $\mathbf{C o}$ & $\mathbf{C r}$ & $\mathbf{C u}$ & $\mathbf{N i}$ & $\mathbf{P b}$ & $\mathbf{Z n}$ \\
\hline \multicolumn{7}{|c|}{ Analytical detection limit, $\mathbf{n g L}^{-1}$} \\
\hline August 2008 & 0.92 & 0.95 & 1.11 & 0.90 & 0.97 & 0.70 & 0.92 \\
\hline January 2009 & 1.68 & 1.80 & 2.11 & 1.75 & 1.84 & 1.35 & 1.75 \\
\hline \multicolumn{7}{|c|}{ Blank value, ngL $^{-1}$} \\
\hline August 2008 & 24.0 & 24.0 & 21.7 & 261 & 43.8 & 31.8 & 633 \\
\hline January 2009 & 38.9 & 4.47 & 1.31 & 721 & 23.0 & 24.0 & 622 \\
\hline \multicolumn{7}{|c|}{ Operational detection limit*, ngL } \\
\hline Both seasons
\end{tabular}




\section{Table 4}

Calculated mean values $\left(\mu \mathrm{g} \mathrm{L}^{-1}\right)$, standard deviations (S.D. in $\mu \mathrm{g} \mathrm{L}^{-1}$ ) and the relative standard deviations (rsd) of DGT-measured concentrations of metals in sites with replicated deployment

\begin{tabular}{|c|c|c|c|c|c|c|c|c|c|c|c|c|c|c|c|c|c|c|c|c|c|}
\hline \multirow[b]{2}{*}{ site } & \multicolumn{3}{|l|}{$\mathrm{Cd}$} & \multicolumn{3}{|l|}{$\mathrm{Co}$} & \multicolumn{3}{|l|}{$\mathrm{Cr}$} & \multicolumn{3}{|l|}{$\mathrm{Cu}$} & \multicolumn{3}{|l|}{$\mathrm{Ni}$} & \multicolumn{3}{|l|}{$\mathrm{Pb}$} & \multicolumn{3}{|l|}{$\mathrm{Zn}$} \\
\hline & mean & S.D & rsd. $\%$ & mean & S.D & rsd. $\%$ & mean & S.D & rsd. $\%$ & mean & S.D & rsd. $\%$ & mean & S.D & rsd. $\%$ & mean & S.D. & rsd. $\%$ & mean & S.D & rsd. $\%$ \\
\hline \multicolumn{22}{|c|}{ August 2008} \\
\hline L01 & 0.09 & 0.02 & 22 & 0.04 & 0.01 & 18 & 0.07 & 0.004 & 6 & 0.18 & 0.03 & 20 & 0.31 & 0.08 & 27 & 0.03 & 0.004 & 13 & 0.50 & 0.13 & 25 \\
\hline L03 & 0.02 & 0.01 & 64 & 0.02 & 0.004 & 17 & 0.03 & 0.01 & 29 & 0.95 & 0.11 & 12 & 0.61 & 0.09 & 15 & 0.02 & 0.002 & 10 & 0.64 & 0.12 & 19 \\
\hline L06 & 0.03 & 0.01 & 17 & 0.03 & 0.004 & 13 & 0.06 & 0.01 & 10 & 1.24 & 0.16 & 13 & 0.93 & 0.10 & 11 & 0.03 & 0.003 & 11 & 2.13 & 0.17 & 8 \\
\hline L09 & 0.07 & 0.04 & 60 & 0.05 & 0.003 & 5 & 0.32 & 0.25 & 76 & 0.64 & 0.06 & 10 & 4.32 & 1.07 & 25 & 0.04 & 0.01 & 17 & 5.45 & 2.50 & 46 \\
\hline $\mathrm{U} 01$ & 0.04 & 0.001 & 12 & 0.04 & 0.003 & 7 & 0.42 & 0.04 & 10 & 0.33 & 0.06 & 16 & 0.61 & 0.09 & 15 & 0.10 & 0.01 & 8 & 25.2 & 3.30 & 13 \\
\hline U02 & 0.03 & 0.01 & 49 & 0.60 & 0.10 & 16 & 0.28 & 0.09 & 30 & 0.60 & 0.04 & 13 & 0.69 & 0.15 & 21 & 0.07 & 0.01 & 12 & 7.21 & 3.13 & 12 \\
\hline U04 & 0.06 & 0.01 & 17 & 0.02 & 0.004 & 21 & 0.05 & 0.01 & 18 & 1.83 & 0.02 & 4 & 0.80 & 0.15 & 19 & 0.04 & 0.01 & 19 & 1.29 & 0.34 & 26 \\
\hline U07 & 0.20 & 0.14 & 70 & 0.16 & 0.10 & 60 & 0.39 & 0.13 & 34 & 1.83 & 0.13 & 7 & 4.85 & 1.91 & 39 & 0.11 & 0.01 & 11 & 13.6 & 9.10 & 67 \\
\hline \multicolumn{22}{|c|}{ January 2009} \\
\hline L01 & 0.03 & 0.03 & 11 & 0.09 & 0.01 & 8 & 0.05 & 0.01 & 21 & 0.79 & 0.18 & 22 & 0.80 & 0.08 & 9 & 0.04 & 0.01 & 26 & 1.11 & 0.13 & 12 \\
\hline L03 & 0.02 & 0.004 & 18 & 0.06 & 0.01 & 11 & 0.04 & 0.01 & 23 & 0.87 & 0.08 & 9 & 0.69 & 0.07 & 10 & 0.04 & 0.01 & 15 & 1.27 & 0.10 & 8 \\
\hline L06 & 0.06 & 0.06 & 11 & 0.03 & 0.003 & 9 & 0.17 & 0.05 & 32 & 2.31 & 0.26 & 11 & 0.65 & 0.13 & 20 & 0.06 & 0.01 & 21 & 2.86 & 0.16 & 5 \\
\hline L09 & 0.13 & 0.01 & 8 & 0.12 & 0.01 & 9 & 0.60 & 0.29 & 49 & 3.03 & 1.11 & 37 & 4.02 & 0.40 & 10 & 0.17 & 0.02 & 13 & 9.54 & 1.44 & 15 \\
\hline U01 & 0.02 & 0.003 & 18 & 0.04 & 0.01 & 19 & 0.05 & 0.01 & 20 & 0.69 & 0.51 & 7 & 0.23 & 0.03 & 12 & 0.07 & 0.01 & 9 & 0.76 & 0.07 & 9 \\
\hline U02 & 0.03 & 0.02 & 66 & 0.08 & 0.001 & 2 & 0.05 & 0.01 & 18 & 1.59 & 0.59 & 37 & 0.43 & 0.08 & 18 & 0.04 & 0.01 & 16 & 1.36 & 0.21 & 16 \\
\hline U04 & 0.04 & 0.01 & 21 & 0.09 & 0.01 & 8 & 0.06 & 0.01 & 14 & 2.20 & 0.22 & 10 & 0.58 & 0.03 & 5 & 0.05 & 0.02 & 18 & 3.23 & 0.41 & 13 \\
\hline U07 & 0.12 & 0.02 & 15 & 0.07 & 0.001 & 2 & 0.23 & 0.01 & 3 & 1.94 & 0.22 & 11 & 2.22 & 0.22 & 10 & 0.10 & 0.02 & 19 & 5.99 & 0.68 & 11 \\
\hline
\end{tabular}




\section{Table 5}

Blank substracted DGT-measured concentrations of trace metals, $\mu \mathrm{g} \mathrm{L}^{-1}$

\begin{tabular}{|c|c|c|c|c|c|c|c|c|c|c|c|c|c|c|}
\hline & \multicolumn{2}{|c|}{$\mathrm{Cd}$} & \multicolumn{2}{|c|}{$\mathrm{Co}$} & \multicolumn{2}{|c|}{$\mathrm{Cr}$} & \multicolumn{2}{|c|}{$\mathrm{Cu}$} & \multicolumn{2}{|c|}{$\mathrm{Ni}$} & \multicolumn{2}{|c|}{$\mathrm{Pb}$} & \multicolumn{2}{|c|}{$\mathrm{Zn}$} \\
\hline & Aug & Jan & $\mathrm{Au}$ & Jan & Aug & Jan & Aug & Jan & Aug & Jan & Aug & Jan & Aug & Jan \\
\hline L01 & 0.09 & $<$ & 0.01 & 0.09 & 0.06 & 0.04 & 0.13 & $<$ & 0.33 & 0.73 & $<$ & 0.02 & 0.15 & 0.30 \\
\hline L03 & $<$ & $<$ & $<$ & 0.06 & 0.02 & 0.03 & 0.85 & 0.12 & 0.51 & 0.62 & 0.02 & 0.02 & 0.47 & 0.47 \\
\hline L06 & 0.01 & 0.02 & 0.003 & 0.03 & 0.04 & 0.13 & 1.10 & 1.80 & 0.82 & 0.54 & 0.03 & 0.05 & 1.99 & 2.03 \\
\hline L09 & 0.05 & 0.09 & 0.02 & 0.12 & 0.30 & 0.59 & 0.62 & 2.33 & 4.28 & 4.01 & 0.04 & 0.15 & 5.19 & 8.82 \\
\hline U01 & 0.01 & $<$ & 0.01 & 0.04 & 0.36 & 0.04 & 0.33 & 0.03 & 0.63 & 0.23 & 0.10 & 0.05 & 27.3 & $<$ \\
\hline U02 & 0.08 & $<$ & 0.02 & 0.07 & 0.48 & 0.03 & 0.66 & 0.20 & 5.03 & 0.37 & 0.04 & $<$ & 6.95 & 0.19 \\
\hline U04 & 0.04 & $<$ & $<$ & 0.08 & 0.02 & 0.05 & 0.59 & 0.89 & 0.65 & 0.41 & 0.05 & 0.02 & 0.78 & 0.64 \\
\hline U07 & 0.18 & 0.08 & 0.13 & 0.07 & 0.37 & 0.23 & 1.81 & 1.24 & 4.81 & 2.20 & 0.11 & 0.08 & 13.3 & 5.27 \\
\hline
\end{tabular}

$<$ blank values was found more than measured concentrations 
Table 6

Correlations between spatial patterns of paired DGT-measured metal concentrations (Pearson's coefficient)

\begin{tabular}{|l|c|c|c|c|c|c|c|}
\hline $\begin{array}{l}\text { summer } \\
\text { winter }\end{array}$ & $\mathrm{Cd}$ & $\mathrm{Co}$ & $\mathrm{Cr}$ & $\mathrm{Cu}$ & $\mathrm{Ni}$ & $\mathrm{Pb}$ & $\mathrm{Zn}$ \\
\hline $\mathrm{Cd}$ & 1 & -0.25 & 0.06 & 0.21 & 0.29 & 0.13 & -0.34 \\
\hline $\mathrm{Co}$ & 0.67 & 1 & 0.26 & -0.21 & -0.13 & 0.42 & 0.65 \\
\hline $\mathrm{Cr}$ & $\mathbf{0 . 9 6}$ & 0.65 & 1 & 0.05 & 0.31 & $\mathbf{0 . 9 0}$ & 0.77 \\
\hline $\mathrm{Cu}$ & 0.87 & 0.49 & $\mathbf{0 . 9 4}$ & 1 & 0.56 & 0.26 & -0.34 \\
\hline $\mathrm{Ni}$ & $\mathbf{0 . 9 9}$ & 0.70 & $\mathbf{0 . 9 6}$ & $\mathbf{0 . 8 7}$ & 1 & 0.23 & -0.17 \\
\hline $\mathrm{Pb}$ & $\mathbf{0 . 9 3}$ & 0.45 & $\mathbf{0 . 8 9}$ & 0.77 & $\mathbf{0 . 9 1}$ & 1 & 0.74 \\
\hline $\mathrm{Zn}$ & $\mathbf{0 . 9 9}$ & 0.60 & $\mathbf{0 . 9 6}$ & $\mathbf{0 . 9 1}$ & $\mathbf{0 . 9 9}$ & $\mathbf{0 . 9 1}$ & 1 \\
\hline
\end{tabular}


Figure 2

Average fluxes of trace metals in the Lopan River (L01-L09) and Udy River (U01-U07) in August 2008 (white bar) and January 2009 (grey bar)
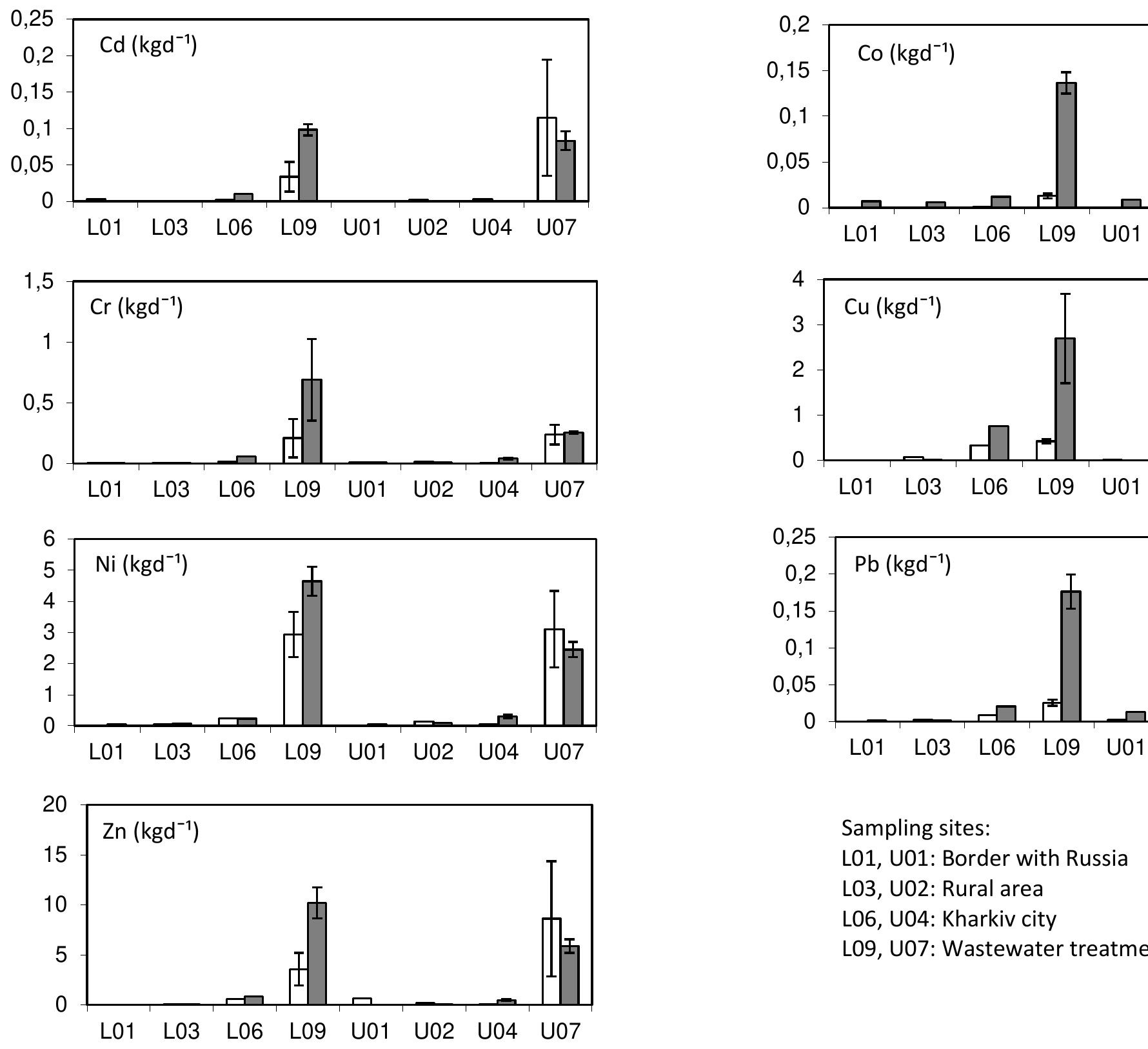

Sampling sites: L01, U01: Border with Russia L03, U02: Rural area L06, U04: Kharkiv city L09, U07: Wastewater treatme 